\title{
Research on the Analysis of Corporate Social Responsibility Based on the Perspective of Economic Law
}

\author{
SiQi Wang ${ }^{1, *}$ \\ ${ }^{1}$ School of Law, Ocean University of China, Qingdao, Shandong, China \\ ${ }^{*}$ Corresponding author. Email: $18150022061 @$ stu.ouc.edu.cn
}

\begin{abstract}
Nowadays, the gap between the rich and the poor in Chinese society is gradually increasing, and has been on the rise. Although the state's regulation through the "invisible hand" is effective, there are still many areas that need to be improved. Based on this, this paper studies the close connection between economic law and social responsibility, and further explores the system construction of corporate social responsibility under the perspective of economic law. The study finds that only by combining the "invisible hand" with the law can we achieve better results. This study aims to promote the long-term sustainable development of Chinese society and economy.
\end{abstract}

Keywords: Economic Law, Social Responsibility, System Building, Sustainable Development

\section{INTRODUCTION}

Society generally believes that enterprises should assume social responsibility. The CSR system requires enterprises not only to make profits, but also to take responsibility for their employees, consumers and society in the process of pursuing their own economic benefits [1]. The pursuit of efficiency is the nature of enterprises, but in order for enterprises to spend a certain amount of time and economic costs to assume a certain amount of social responsibility, it requires not only a good social system and a standardized corporate system to guide, but also a high sense of social responsibility on the part of enterprise leaders [2]. With the development of the times, Chinese enterprises have made great progress in assuming social responsibility, but their current situation is still not optimistic. The study of CSR and the reference to the modern CSR system in Japan are of great significance to the improvement of CSR in China. The research on CSR in Chinese academia has made some achievements, but the research on CSR system in China is still in its infancy. Enterprises are obsessed with pursuing economic benefits and neglecting social responsibility, which has led to the frequent occurrence of mass time, such as "network security accidents" and "hazy weather". How to build a social responsibility system for enterprises and make them take more social responsibility has become a difficult problem for the society at present [3]. However, the current situation of corporate social responsibility is still not optimistic, which is a problem we need to face urgently. Especially for China, the socialist market economy system is still not perfect, and enterprises are always pursuing the maximization of corporate interests, in the process, they often ignore the issue of corporate social responsibility. Some people think that the assumption of corporate social responsibility is [4]. A social moral issue, but its essence is also a legal issue, which is closely related to economic law. This paper argues that it is extremely important to study the issue of corporate social responsibility from the field of economic law. Based on this consideration, this study was born under the vision of economic law. It is hoped that the research of this paper can contribute to the improvement of the social responsibility of Chinese enterprises.

\section{THE CLOSE CONNECTION BETWEEN ECONOMIC LAW AND SOCIAL RESPONSIBILITY}

\subsection{Consistency between the social interest- based nature of economic law and corporate social responsibility}

As an independent part of the Chinese legal system, 
the interests regulated by economic law may be the same as those of other legal departments, but the focus is different. As we know, civil law regulates the property and personal relations between equal subjects, administrative law regulates specific administrative relations, referring to the various relationships arising from the use of power by the state administrative organs. The economic law is based on the social orientation and adjusts an economic relationship, but not all economic relationships are adjusted by the economic law, which only solves macroeconomic relationships and microeconomic relationships formed by the government in the process of normal coordination of economic operation, which means that there is a scope of the adjustment object of the economic law, which only adjusts specific economic relationships, not other economic relationships, and does not adjust noneconomic relationships [5]. It only regulates specific economic relations, not other economic relations, and does not regulate non-economic relations. When economic law is based on social orientation, it must safeguard the overall interests of the society, and must focus on the overall situation, which is to achieve the stable development of the society by finding a golden point between the overall interests of the society and individual interests.

\subsection{Consistency between the value orientation of economic law and corporate social responsibility}

In layman's terms, the value of something means that it is useful to us, and the value of economic law is no exception. The needs of people vary from person to person, and the needs of each person are often different from those of other people, so the value of economic law can have many levels. The value of economic law has basically formed a consensus in the field of economic law, the value of China's economic law is reflected in the harmony and unity of substantive justice, social efficiency, economic freedom and economic order, which in fact has a high similarity with the social responsibility that enterprises should undertake, if enterprises really need to undertake the corresponding social responsibility, they also need to achieve the above unity.

\subsection{The balance and coordination role of economic law and the consistency of corporate social responsibility}

Unlike other legal departments, which are relatively specific and single in terms of objects and objects, economic law is a relatively broad category, focusing more on the coordination of the interests of economic subjects to achieve a reasonable allocation of limited resources in society [6]. In our real life, economic development also requires government departments to allocate the limited resources of the whole society within the framework of the law, to meet both efficiency and fairness. How to grasp this point, the government needs to have a proper strategy and strong adjustment tools, and economic law can meet this point, based on the characteristics of economic law itself, it has a strong comprehensive, balanced and certain coordination. Therefore, in order to make the economic and social development smooth and fast, and make the social conflicts within a controllable range, the most effective way is for the government to use the powerful weapon of economic law to make a reasonable allocation of limited social resources, so as to solve the social conflicts and promote the harmonious development of the economy and society.

\subsection{Consistency between the unique adjustment method of economic law and corporate social responsibility}

From the above discussion, it is clear that the inherent meaning of economic law is consistent with the social responsibility that enterprises should undertake. Economic law, like other laws, has its own specific adjustment objects and methods. Here, we focus on the specific adjustment method of economic law, which is a combination of punitive and advocacy, and is relatively flexible in terms of operation. The role of economic law is to ensure the stability and normal operation of the national economy, and because of the diversity of the country's economic development, economic law also adopts a combination of directive methods and guiding and encouraging methods in the process of adjusting the national economy.

\section{AN EXAMINATION OF CSR IN PRACTICE}

\subsection{The Current Situation of CSR in China}

\subsubsection{Whether Chinese enterprises need to assume social responsibility in the perspective of economic law}

With the passage of time, technological innovation is changing day by day, causing profound changes in all aspects of society, and enterprises, as the core participants of the market economy, should assume more social responsibilities. When we raised this issue, of course, there were many opposing voices, arguing that enterprises, as a civil and commercial subject, should assume more civil and commercial responsibilities, but not social responsibilities, because we know that enterprises should assume social responsibilities, which means paying more to society. Based on this incorrect understanding, we believe that it is more urgent and urgent to make enterprises assume 
corresponding social responsibilities from the perspective of economic law. In the decades after the reform and opening up, China's economy has developed rapidly and achieved world-renowned achievements, but along with these achievements, some serious social problems have also occurred, such as food safety, environmental pollution, and damage to workers' rights and interests [7]. The reason for these serious social problems has a lot to do with our lack of attention to corporate social responsibility, and we have done even less to think about this issue from the perspective of economic law. Therefore, there is no doubt that Chinese enterprises need to take social responsibility under the current environmental situation.

\subsubsection{The new direction of Chinese enterprises' social responsibility}

The above mentioned problems in the fulfillment of social responsibility of Chinese enterprises are essentially the social responsibility that enterprises should undertake in the traditional sense. 2016, the three international standards of social responsibility began to operate, which put forward new requirements and indicated new directions for Chinese enterprises to undertake social responsibility. The specific contents are as follows:

1. accelerate the construction of corporate social responsibility and enhance the awareness of corporate green responsibility.

2. Poverty alleviation is an important manifestation of fulfilling corporate social responsibility.

3. The fulfillment of corporate social responsibility is presenting new requirements.

4. Participate in global governance and promote the construction of overseas social responsibility.

\subsection{Legislative Provisions of Corporate Social Responsibility in China}

At present, there are only broad provisions in the Company Law, which only say that enterprises cannot violate the provisions of laws and regulations in the process of production and operation, cannot violate the public order and morality of society, and must accept the supervision of society and bear the corresponding social responsibility [8]. The Labor Law of the People's Republic of China and the Interpretation of the Supreme People's Court on Several Issues Concerning the Application of Law to the Trial of Labor Dispute Cases are mostly about the protection of workers' rights and interests. However, the spirit of protecting the rights of the weak coincides with the essence of social responsibility of enterprises. The newly revised Food Safety Law of the People's Republic of China (hereinafter referred to as "Food Safety Law") came into effect on October 1, 2015. With the implementation of the new Food Safety Law, it is of great significance to ensure food safety. The current food safety problems in China have become alarming and have caused great potential danger to people's lives. The new Food Safety Law amplifies the consumer's right to compensation for food injuries, making it more flexible and convenient for consumers to seek compensation from both the seller and the producer of food.

\section{STYLE PALETTE}

\subsection{Establishing a perfect legal system of economic law}

In China's current national conditions, the social responsibility of enterprises is more dependent on morality. In the legal system, the social responsibility of enterprises is mainly concentrated in the Company Law, the Protection of Consumer Rights and Interests Law, the Product Quality Law, the Environmental Protection Law, the Labor Law, the Law on Enterprises Owned by the Whole People, the Law on Partnership Enterprises, and the Law on Sole Proprietorship Enterprises. However, these laws have few direct provisions, and even if there are provisions, they are not in line with the actual situation and do not have a good effect. Therefore, how to reach a consensus between the social responsibility of enterprises and the pursuit of their own reasonable interests needs to be further defined by law. In the future legislative direction, the provisions of this part should be highlighted, so that the content of social responsibility of enterprises is clear and specific, and the implementation is convenient and effective.

\subsection{Combining Judicial Decisions with Other Approaches}

Corporate social responsibility is also actionable, for example, the Indonesian Company Law provides in Article 72 that "companies operating in or related to the natural resources industry have social and environmental responsibilities .... Companies that do not fulfill their responsibilities as described above are punishable by law". In fact, many provisions of China's economic law are similar to those of Indonesia, and the application of judicial provisions alone is not sufficient to adapt to the actual social situation, so that those cases that do not need to be resolved through judicial procedures can be referred to reconciliation, civil mediation or administrative processing, which requires the improvement of legislative provisions to meet the ever-changing social reality.

\subsection{Strengthening the enforcement of laws}

Our current legislative situation is that there are many oaths and few punitive clauses, and the punitive 
clauses are not strong enough. Under the effect of these two factors, the cost of breaking the law for many enterprises is greatly reduced, or is much lower than the benefit they can get from breaking the law, so it does not really play a warning effect, nor does it achieve a social effect that we expect [9]. In addition, even if the legislation is clear, just by virtue of the perfect legal provisions cannot guarantee that enterprises can well fulfill their legal and social responsibilities. Here we require our law enforcement agencies in the specific law enforcement process, must be strictly in accordance with the requirements of laws and regulations, strict law enforcement, do their own work, to play a legal warning role. Especially for the people's livelihood of food safety, personal safety of administrative law enforcement, more cannot relax the vigilance. In this paper, we believe that safety is the basis of human survival and development, which needs special attention, and therefore should be the common pursuit of many legal adjustment values, which needs to be given sufficient attention.

\subsection{Improve legal supervision and incentive mechanism}

This paper argues that China, while taking into account its own special national conditions, can also learn from the valuable experience of other countries and be able to establish a corporate social responsibility system that is basically in line with the world's social responsibility standard system. With the widespread use of the Internet and the development of economic globalization, many foreign enterprises have come to China for development, and such an idea has become a practical possibility [10]. The construction and improvement of CSR requires the joint efforts of the whole society and the cooperation of many aspects of society, among which the government's supervision and encouragement of enterprises are particularly important. At the same time, it is important to deepen the public's understanding of CSR, strengthen the consciousness of each subject to undertake CSR, and create an atmosphere of common fulfillment of CSR. To fundamentally improve enterprises' social responsibility awareness and ability, and to establish a CSR with sustainable development characteristics, we can consider the following aspects.

\subsubsection{Requirements for the state (government)}

Socialist market economy with Chinese characteristics emphasizes both the role of the market and the role of macro-control, which requires the government to play a full role in guiding and supervising the development and operation of enterprises, in order to promote the effective implementation of corporate social responsibility. As the "superior" of enterprise management, the government should strictly abide by and implement the law, and at the same time, it should also flexibly use the government's identity to establish a long-term incentive mechanism to restrain the economic activities of enterprises, so as to promote the correct fulfillment of social responsibility. In addition, the judicial organs should also conscientiously fulfill their responsibilities, and the people's procuratorates and people's courts should strengthen law enforcement and punish enterprises severely for illegal and criminal acts, so as to truly achieve judicial fairness and justice, in order to urge enterprises to actively abide by the law and properly fulfill their social responsibilities.

\subsubsection{Requirements for social opinion}

With the development of economy, social media gradually grows up and becomes a powerful team for enterprise supervision. The media places enterprises in the public eye, provides a broader platform for enterprise information disclosure, enables the public to have a more comprehensive understanding of enterprise information, and also improves the self-discipline of enterprises. On the one hand, as a disseminator of public opinion, the media should uphold the concept of justice, and should provide true, timely and objective reports on corporate wrongdoings and violations as well as positive behaviors, without distorting facts or yielding interests, and truly become a disseminator of positive energy in society. On the other hand, with the progress of society, consumers' awareness of their rights is increasing, and consumer organizations are playing a pivotal role in monitoring the fulfillment of corporate social responsibility [11]. With the growing strength of consumers and consumer organizations, enterprises will not be driven by profit alone in their business decisions and product orientation, but will take into account the interests of consumers, and will consciously engage in self-reflection and self-restraint, thus contributing to the construction of corporate social responsibility. Finally, as the object of supervision, enterprises should be brave enough to put themselves under the supervision of public opinion, proactively improve their internal information disclosure system, accept public opinions, and take positive actions to make up for their shortcomings [12]. In order to fundamentally solve the problem of CSR construction, besides using the above methods, we also need the joint efforts of all walks of life to raise the awareness and pursuit of CSR from the ideology and consciousness, and to create an atmosphere of joint fulfillment of social responsibility in order to establish more sustainable enterprises..

\subsection{Improve the internal governance mechanism of corporate social responsibility}

The above discussion of corporate social responsibility, mainly from the external conditions and environment, in fact, corporate social responsibility can 
not be undertaken without the constraints of internal governance institutions. The current laws and regulations, such as the Company Law and its judicial interpretation, emphasize the rights of shareholders' meeting, board of directors and supervisors to ensure the stable and efficient operation of the company and to maximize the rights and interests of shareholders and directors. Therefore, it is necessary to strengthen the content of corporate social responsibility in these chapters of the Company Law and the company's articles of incorporation. Specifically, the company should increase the number of stakeholder representatives, and strengthen and clarify their responsibilities, so that stakeholders are not just a virtual void, so that their reasonable opinions can be adopted. In addition, the company should make public the important matters and information related to stakeholders without affecting the company's business secrets, which is actually a reflection of the enterprise's responsibility to itself.

\section{CONCLUSION}

Nowadays, China's economic and social income gap has been showing a widening trend, and various social contradictions have become more and more prominent. It is more and more necessary for the state to adjust the economic development through the "invisible hand". Economic law is one of the most important means of regulation, and the state can make up for the uneven distribution of society by using this powerful weapon. In view of this, it is necessary and significant for us to discuss here how enterprises can assume social responsibility from the perspective of economic law. This paper attempts to discuss the establishment of corporate social responsibility system from the perspective of economic law, hoping that it can have some significance for the distribution of benefits, environmental protection, and the protection of workers' rights and obligations in China's economy and society.

\section{REFERENCES}

[1] He L. China-US trade war and the direction of international economic law under counter-globalization[J]. Political Law Series, 2019(05): 3-14.

[2] Zhang S. Trade war, global economic governance and the improvement of economic law [J]. Journal of Wuhan University (Philosophy and Social Science Edition), 2019, 72(05): 5-15.

[3] Cheng, X. The original theory of the general rules of economic law [J]. Local legislation research, 2019, 4(01): 54-129.

[4] Zhang S. Economic law to fill the gap in the construction of modernized economic system[J]. Modern jurisprudence, 2018, 40(06): 54-63.
[5] Liu D. On the principle of market priority in economic law:connotation and application[J]. Law and Business Research, 2017, 34(02): 82-90.

[6] Zhang S. New development of economic law theory in China[J]. Politics and law, 2016(12): 212.

[7] Zhao D. On the economic legal responsibility of power subjects in economic law $[\mathrm{J}]$. Law and Business Research, 2016, 33(05): 66-74.

[8] Zhang S. Legislative unification of economic law:the need and possibility[J]. Modern jurisprudence, 2016, 38(03): 62-70.

[9] Liu S. What is economic law--reflection on the legal philosophy of economic law [J]. Politics and Law, 2014(08): 87-102.

[10] Zhang S. "Reform decision" and economic law consensus[J]. Law Review, 2014, 32(02): 13-24.

[11] Ying Feihu. Some issues of economic law implementation in China[J]. Modern jurisprudence, 2013, 35(05): 61-67.

[12] $\mathrm{Lu} \mathrm{D}$. The protection of the overall interests of society by economic law[J]. Modern jurisprudence, 2013,35(04): 24-31. 